The Labor/Land Ratio and India’s Caste System

Harriet Orcutt Duleep

(Thomas Jefferson Program in Public Policy, College of William and Mary

and IZA- Institute for the Study of Labor)

College of William and Mary

Department of Economics

Working Paper Number 137

March 2013 
COLLEGE OF WILLIAM AND MARY

DEPARTMENT OF ECONOMICS

WORKING PAPER \# 137

March 2013

\title{
The Labor/Land Ratio and India's Caste System
}

\begin{abstract}
This paper proposes that India's caste system and involuntary labor were joint responses by a nonworking landowning class to a low labor/land ratio in which the rules of the caste system supported the institution of involuntary labor. The hypothesis is tested in two ways: longitudinally, with data from ancient religious texts, and cross-sectionally, with twentieth-century statistics on regional population/land ratios linked to anthropological measures of caste-system rigidity. Both the longitudinal and cross-sectional evidence suggest that the labor/land ratio affected the caste system's development, persistence, and rigidity over time and across regions of India.
\end{abstract}

JEL Codes: J47, J1, J30, N3, Z13

Keywords: labor-to-land ratio, population, involuntary labor, immobility, value of life, marginal product of labor, market wage

Harriet Duleep

Thomas Jefferson Program in Public Policy

College of William and Mary

Williamsburg VA 23187-8795

hduleep@wm.edu 


\section{The Labor/Land Ratio and India's Caste System}

\section{Background}

Several scholars have observed that, historically, the caste system was more rigid in south India than in other parts of India. In the 1930's, Gunther (1939, p. 378) described south India as the “...home of Hinduism in its most intensive form...virtually a disease.... The place to go to inspect rigidity of caste, orthodoxy in observance, and misery among the untouchables.” Discussing social stratification in modern India, Bhatt (1975, p. 57) wrote, "Traditionally in the south the severities of caste have been felt more acutely than in the west or the north. Low status castes even in pre-independence days had relatively less civic and economic deprivation in a region like Gujarat than in Kerala or Tamil Nadu. In the south there was not only untouchability, but also unapproachability and unseeability.” In defining the lower castes and the types of disabilities imposed against them, such as being denied access to temples, use of separate wells, and not being permitted inside a school house, Hutton (1931) wrote in the 1931 British Census of India, “These disabilities vary in different parts of India, being more severe in the south of India than elsewhere.” In his detailed analysis of South Indian agricultural labor, Kumar (1965, p.5) comments, “...it is in South India that the caste system was peculiarly rigid.”

The finding that the caste system was strongest in the south is odd when one considers the historical, linguistic, and cultural backgrounds of southern and northern India. All of the languages spoken by Indians south of the Vindhyan mountain range ${ }^{1}$ - Tamil, Telegu, Kannada, Malayalam—

\footnotetext{
${ }^{1}$ The Vindhya Range is commonly cited as marking off the Dravidian area. For instance, Columbia Encyclopedia (2011) states: "The Vindhya Range has been the historic dividing line between N and S India, separating the Sanskrit-speaking Aryan invaders from the Dravidian peoples...” A more precise description of the dividing line is given by Jones (1989): "The northern border of the Dravidian South begins on the east coast at the southern edge of Orissa, runs roughly along the northern lines of the Godavari River as it flows through the central Deccan, dipping south-west to Goa. The remainder of peninsular India extends to the southernmost tip of the mainland.... Each
} 
derive from the ancient tongue, Dravidian. ${ }^{2}$

The languages north of the Vindhyan Mountain range are Indo-European. They derive from the language of the Aryans. The Aryans came from a group of ancient Indo-European speaking tribes who divided up and migrated in all directions from a heartland, some moving westward to inhabit Europe, others moving eastward through the Afghan passes and settling in the Indus and Ganges plains of north India (Figure 1). The Aryans are those who entered India. They spoke Sanskrit from which Hindi and the other modern north Indian languages evolved.

The Aryans brought with them the Rig Vedas, a collection of hymns that were gradually compiled into ten great books around 1000 B.C., forming the cornerstone of Hinduism. ${ }^{3} 4$ Thus Hinduism could be considered an Aryan development. ${ }^{5}$ The Aryans' center of Hinduism was in northern India between the Ganges and the Jumna rivers. ${ }^{6}$ The central focus of this paper is an historical feature of Hinduism—-the caste system.

cultural and linguistic subdivision of the South radiates out from a core and blends into the others without clearly defined borders. The areas of each of the four languages — Telugu, Tamil, Kannada, and Malayalam — roughly correspond to the four southern states of India: Andhra Pradesh, Tamilnadu, Karnataka, and Kerala.”

${ }^{2}$ The linguistic histories of south and north India are discussed in Allchin and Allchin (1982), Mabbett (1970) pp. 6-18, Wheeler (1968), Hutton (1961, pp.2-5, 10-14, 22-26) taken from Hutton (1931), Murdoch (1977, pp. 14-15), Gunther (1939, pp. 373-375), and Lethbridge, (1881, pp. 137-152).

${ }^{3}$ Refer to Mabbett (1970, pp.12, 16-20) and Rapson (1922, pp.697-703).

${ }^{4}$ In an effort to make this paper generally accessible, I am using the term Hinduism loosely. More precisely, Hinduism succeeded Brahmanism.

${ }^{5}$ This statement simplifies Hinduism's development in light of recent archaeological evidence that suggests a dynamic process of cultural contact between the entering Aryans and the indigenous population (Allchin and Allchin, 1982; Possehl, 1982). Kolenda (1978, p. 29) comments: "Hinduism and the Hindu caste system emerged from a blending of the culture of the Aryans and the cultures of the people already in northern India, probably including the descendants of the sophisticated city-dwellers of the Indus Valley." In discussing the Indus Valley civilization and its relationship to the Aryans, Gould (1987, pp. 84-5) writes: “Among the excavated sites from which our knowledge of this civilization comes [were] ... terra cotta seals imprinted with typical symbols of later Hinduism like the cobra, the Brahma bulls, and holy men sitting in the yoga posture.... At any rate, the coming of the so-called Aryans around 1,500 B.C. heralds the commencement of conditions in India which lead directly to the creation of a highly variegated system of castes.... The Hindu religious classics reveal a gradual crystallization of a caste ethic which divides society into a hierarchy of four morally intrinsic, occupationally-specific strata: Priests (Brahmans), Warriors and Rulers (Kshatriyas), Traders, Artisans and Cultivators (Vaishyas), and Menials (Sudras)."

${ }^{6}$ Refer to Mabbett (1970, pp.4-6), Hutton (1961, p.33) and Gunther (1939, pp.373-375). 
In contrast with the north, the Aryan influence in the south was relatively small, the lands south of the Vindhyan range remaining under the rule of southern-based kingdoms of Dravidian origin. In this way the language division between north and south India persisted, the tongues of the north reflecting their Aryan origin, and those of the south their Dravidian roots. ${ }^{7}$

In addition to language differences, there have been dramatic cultural differences between southern and northern India. ${ }^{8}$ Hinduism proffered a patriarchal system and north India was characterized by a patrilineal system. In the south, there have been several matrilineal peoples. Kerala, considered a stronghold of the ancient Dravidian culture, practiced inheritance of property and family name through the woman up until the passage of special legislation in the early twentieth century (Hutton, 1961, pp. 10-13). There is also some evidence that in parts of the south women played a prominent role in political and economic life. Inscriptions from the second century B.C. to third century A.D. depict women making costly donations, including land grants, along with actively participating in political assemblies (Gopalachari, 1941, pp. 90-98).

The persistence of a matrilineal system in parts of south India has been attributed to its landward isolation from the rest of India (Hutton, 1961). Yet, why did the south, which maintained Dravidian-based languages and did not fully adopt the Aryans’ patriarchal system, surpass the north with regard to the caste system?

This paper explores a novel hypothesis of the caste system that may shed light on this historical paradox. I hypothesize that the caste system and involuntary labor (serfdom or slavery) were joint responses by a nonworking landowning class (Brahmans and Kshatriyas) to a low

\footnotetext{
${ }^{7}$ Refer to Lethbridge (1881. p. 148), Mabbett (1970, pp. 1-14,68-75), and Hutton (1961, pp. 2-5, 10-14, 22-26, 41). ${ }^{8}$ Refer to Kolenda (1978), Sharma (1958), Agarwal (1965), Goshal (1973), Hutton (1961), Lethbridge (1881, pp. 148149), and Gopalachari(1941).
} 
labor/land ratio in which the rules of the caste system supported the institution of involuntary labor.

My hypothesis encompasses two components. One, the caste system fulfilled functions

facilitating the enserfment or enslavement of the lowest castes, subsumed in the major caste category

Sudra. ${ }^{9}$ Two, the development of both the caste system and involuntary labor were responses to a

low labor/land ratio.

Part II presents evidence for the first component of the hypothesis: It suggests ways in which the rules of the caste system supported the institution of involuntary labor. ${ }^{10}$ The arguments resonate with themes in Stanley Engerman’s scholarship (Engerman, 1973, 1992): the psychic costs for slave owners of enslaving people are lower if the enslaved group is distinct (or can be made to be distinct) from the owners, and the costs of enforcing property rights in people are lower if the enslaved can be readily distinguished from the free population.

Part III provides background information on the second component of the hypothesis (the caste system and involuntary labor were joint responses to a low labor/land ratio): It describes Evsey Domar's hypothesis linking the labor/land ratio to involuntary labor and then extends it, with qualification, to India’s caste system. Longitudinal data (Part IV) and cross-sectional data (Part V)

\footnotetext{
${ }^{9}$ This paper focuses only on the major caste categories called "varna”. The four varnas are Brahmans, Kshatriyas, Vaishyas, and Sudras. Srinivas (1952, p. 94) writes “...the ancient varnas function as a pan-Indian scheme.... They can be considered to form an all-India caste system.” Within each caste category, or varna, there are numerous castes or "jatis" (endogamous descent-groups), perhaps totaling two-thousand in all (Barnabas and Mehta, 1965, pp. 1-2; Hutton, 1961, pp. 2-4). For instance, Kolenda (1978, p. 21) writes, "Even within the same region, there may be a number of different Brahman jatis [castes].... In Tamilnadu, the Tamil Brahmans are divided into various groups usually referred to as sub-castes: the Vadamas, the Vatimans, the Astasahasras, and so on. Furthermore, these are divided into regional groups. There are Choladesha Vadamas and Vadadesha Vadamas, for example. The Choladesha Vadamas are a jati originally located in the country of the ancient Chola Kingdom, the valley of the Kaveri River. A Vadama will not marry a Vatiman, an Astasahasra, or a Vadadesha Vadama -- only a Choladesha Vadama. From the point of view of a non-Brahman of Tamilnadu, all of these are just Tamil Brahmans.” On the distinction between caste category (varna) and caste (jati), also refer to note 20.

${ }^{10}$ The observation that involuntary labor and the caste system were closely linked is not new. For instance, Kumar (1965, p.34) notes, "One of the most striking and important peculiarities of the Indian forms of servitude is their close connection with the caste system. Most types of servile status were hereditary, and in general the 'serfs' and 'slaves'
} 
test the combined hypothesis.

Given the many differences that separate south and north India, such as the north's greater interaction with outside forces, the hypothesis put forth in this paper is but one of several possible explanations for the historical severity of the caste system in the south. This caveat and others form the paper's penultimate section: Section VI describes limitations of my endeavor that point to new directions for future research. Part VII summarizes the paper’s conclusions.

Many studies of the Indian caste system dwell on its uniqueness and shy away from comparing it to the stratification systems of other societies. My hypothesis is broadly consistent with the work of Harold A. Gould (1987) and Murray Milner (1994) who promote a more universal perspective. ${ }^{11}$ Gould writes,

Although scholars...are right in insisting that India's caste system is, in its ethnographic manifestations, a unique sociocultural phenomenon, they are wrong in implying that for this reason the system has come about by processes that are fundamentally different from the way in which systems of social stratification have come into existence at other points in time elsewhere in the world. (Gould, 1987, p. 33)

\section{The Caste System and Involuntary Labor}

A common feature of slavery and serfdom is that slaves and serfs are not free to move, the slave being tied to a master, the serf to land. As a consequence, competitive wages cannot be established.

Taking away the freedom to move of a group of people does not occur in a legal and social void. It incurs psychic costs to the elite group that are a function of how distinct the suppressed group is from the elite group, as well as the material costs of enforcement (Engerman, 1973, 1992). 
Embedded in this paper's hypothesis is the proposition that the caste system evolved to provide the legal and moral structure to lower the enforcement costs of specifying and maintaining property rights in people. More specifically, the caste system encompassed laws to justify, enforce, and perpetuate the involuntary servitude of the lowest castes subsumed in the major caste category, Sudra.

In discussing the psychic costs of slavery, Engerman (1973, p. 60) notes:

...the costs of the imposition of the system and acquisition of slaves... include moral and religious scruples.... When slaves were derived mainly from war captives, all of these costs of acquisition were low, since there was little psychic difficulty in enslaving foreign enemies, especially if they were of different religion and culture.

In a similar vein, one could argue that the caste system lowered the psychic costs associated with the enserfment/enslavement of the Sudra by promulgating the Sudras' lesser value relative to members of the other caste categories. ${ }^{12}$ According to Hindu doctrine, Brahmans, Kshatriyas, and Vaishyas, three of the four major caste categories (referred to as varna) had twice-born status, the first birth being the actual physical birth, the second, a symbolic spiritual birth initiating them into the fold of Hindu society, represented by a thread worn across the chest. The fourth caste category, the Sudra, was not considered twice-born and thus were without religion, or godless.

Rules regulating rituals and everyday social interaction further vilified the Sudra. Many of these rules emphasized the impurity of the Sudra. Sudras were not allowed to take part in religious ceremonies because they might "pollute" members of other varna. Similarly, in forms of social interaction such as eating, direct or indirect contact might pollute a member of one of the higher

\footnotetext{
${ }^{11}$ The work of Milner (1994) pursues the provocative idea of status, or symbolic capital, as a key resource, with sacredness being a form of status.

${ }^{12}$ Refer to Dumont, (1970, Appendix C), Hutton (1961, Appendix A), Mabbett (1970, p.33), Sharma (1958, pp.77-78, 109-110), and Lethbridge, 1881, pp. 155-156.
} 
varna. $^{13}$

In meting out punishments, the laws of the caste system clearly placed a lower value on a Sudra's life. If a Brahman abused a Kshatriya or a Vaishya, he had to pay a fine; if the victim were a Sudra, no fine was stipulated. If a Sudra abused a member of one of the three higher caste categories, harsh and generally corporal punishment was prescribed. The lowly value once allotted to a Sudra's life is underscored by the fact that the punishment specified for killing a Sudra was, at one time, the same as that for killing a flamingo, a peacock, a crow, or a muskrat!

Engerman (1973, p. 61) notes, ...the costs of enforcing the slave condition...include...the costs of preventing runaways among the enslaved.... [These] costs were lowered by ... having slaves with particular distinguishing features....

The caste system included several rules to distinguish Sudras from the rest of the population and thereby help enforce their involuntary servitude. ${ }^{14}$ In some areas Sudras were required to wear a black thread around the neck and to carry a broom strapped from the waist to sweep away the dust they walked on, lest a twice-born be polluted. In other regions, Sudras were required to have a shaved head with a top knot. In one area of the south, Sudras had to carry a spittoon around the neck. Modes of address were similarly defined to identify the Sudra; in conversation, Sudras were never to assume a position equal to that of a twice-born.

Rules preventing marriages between Sudras and higher varna individuals could also be viewed as a mechanism to lower the enforcement costs of involuntary labor since individuals who are the products of mixed marriages would impair the ability to easily identify members of the Sudra

\footnotetext{
${ }^{13}$ Prohibitions on marriages and liaisons between Sudras and higher varna individuals also served to lower the value of the Sudra relative to those who were suppressing their right to move.

${ }^{14}$ Ambedkar, 1968, p.22; Sharma, 1958, pp.95-97, 107; Hutton, 1961, pp.200-201.
} 
varna. Engerman (1973) suggests a similar motivation underlying the frequent ban on manumission in slave-owning societies.

Finally, the caste system included rules to perpetuate the Sudra's enslavement or enserfment (Sharma, 1958, pp.57, 66, 104). Caste laws excluded Sudras from all political representation and education, tools that could have been used to rid themselves of the restriction on their movement. Diminishing the possibility of their revolt, caste laws prohibited Sudras from carrying arms.

These examples suggest that the caste system fulfilled functions lowering the costs of enserfing or enslaving the Sudra. And yet, considerable variation in the extent or "rigidity" of the caste system occurred over time and across India's regions.

\section{Involuntary Servitude and the Labor/Land Ratio}

The other part of this paper's central hypothesis is that the development of the caste system and the development of serfdom or slavery jointly responded to the scarcity of labor relative to land.

Based on the transition of peasants to serfs in Russia, Domar hypothesized that, given a class of nonworking landowners, free land and free peasants cannot coexist, the support of the landowners being inadequate via economic mechanisms alone (Domar, 1970, 1989). ${ }^{15}$ More specifically, with free labor and abundant land, the wages of the peasants would have been pushed up to the value of the marginal product of labor as landowners competed for this scarce factor. Land being abundant, the competitively established wage would be close to the average product, hence little rent could be derived from the ownership of land. In order to insure the support of a large class of landowners, the "solution" was to take away the peasants' right to move, either by attaching them to the land or its

\footnotetext{
${ }^{15}$ Also refer to Nieboer (1971).
} 
owner, since bonding labor to the land or its owner does away with competition among employers.

Domar's theory does not explain the development of a nonworking landowning class (non-working in the sense of not working on their land). This constrains its predictive value to the expectation of a positive correlation between a low labor/land ratio and serfdom or slavery. In this regard, two observations can be made that may help elucidate India's history of involuntary labor. First, to have a landowning class requires that settled agriculture has already developed. Secondly, the support of such a class from rents derived from involuntary labor requires coordination among the dominant groups; the enforcement of involuntary labor would otherwise be impossible. In the absence of such agricultural and political developments, a servitor class would support itself with tribute and booty, although a tendency to move towards a less erratic form of support, such as a land revenue system, would likely be ever present.

As for the end of involuntary labor, Domar hypothesized that a rise in population with a given quantity of land should, ceteris paribus, lower labor's marginal productivity and the market wage. The landowning class could then reap a rent simply with the aide of market forces, and without the costs associated with serfdom and slavery. Domar concluded that the best antidote to involuntary labor is an increase in the labor-to-land ratio. ${ }^{16}$

Capital formation, Domar pointed out, sets into motion countervailing forces. On the one hand, ownership of capital (not easily accessible to labor) allows the landowner to reap a rent. Also, depending on the nature of technological change, the productivity of free labor may exceed that of unfree labor. Both tendencies would work towards making free labor more likely. Yet, the wage of

\footnotetext{
${ }^{16}$ Further discussion concerning the demise of involuntary labor is in "Part VI: Caveats and Directions for Further Research.”
} 
free labor may rise, whereas this need not be the case with serf or slave labor. ${ }^{17}$ For these reasons, the ratio of population to land is a better predictor of the end of serfdom or slavery in countries and time periods lacking technological change and capital formation. The labor/land theory may be particularly applicable to India’s history.

This paper extends Domar’s labor/land thesis, and Engerman’s insights concerning the enforcement costs of involuntary labor, with the idea that the caste system was the legal structure supporting the development and maintenance of involuntary labor. Accordingly, the evolution of the caste system should have responded to the same economic pressures as the development of involuntary labor; the intensity of the caste system should have varied inversely with the relative abundance of labor. This would explain variations in the rigidity of the caste system at any one time across regions in India and its transformation over time by region.

The hypothesis is tested in two ways: (1) with longitudinal data, using over time information from religious texts and other sources on the labor/land ratio, involuntary labor, and the rigidity of the caste system; (2) with cross-sectional data, using measures of the rigidity of the caste system across regions of India to the labor/land ratios of those regions.

\section{Historical Analysis}

The historical analysis first traces the development of involuntary labor and the caste system using ancient Hindu texts written by north Indian priests. This first analysis thus pertains only to north India. Much of the relevant information comes from a detailed documentation of the Sudra caste by R.S. Sharma (1958). Starting with the period when the Aryans are first thought to have

\footnotetext{
${ }^{17}$ As noted in Domar's discussion of the evolution of west European versus Russian or East European serfdom (Domar,
} 10 
entered India, the time horizon is divided into periods corresponding to developments in the presence of a nonworking landowning class and the labor/land ratio; for each of these periods, the extent of involuntary labor and the caste system are examined. Fortunately, the ancient religious texts provide coincident information on the labor-to-land ratio, the development of a landowning class, the extent of involuntary labor, and the rigidity of the caste system; information on all four variables is generally available within any one text. Thus, it is possible to say with some certainty that one development concurred, or did not concur, with another development even though the specific dates assigned to the periods described below are only estimates based on several references.

The definitions in the Hindu scriptures of the caste system and varna are key to the historical analysis. ${ }^{18}$ Varna refers simply to a division of labor encompassing four classes: Brahmans taught and were ritual specialists; Kshatriyas protected and governed; Vaishyas were herdsmen, craftsmen, and merchants; and Sudras were physical laborers. Varna, in and of itself, implies no gradation of superiority and no restriction on intermarriage or any form of social interaction. According to the ancient scriptures, varna was not necessarily inherited but was determined by one’s qualities and actions. $^{19}$

The caste system used the same division scheme as varna. ${ }^{20}$ However, whereas varna was a

1989, p.xvii), the serf's allotment of land may change.

${ }^{18}$ Hutton, 1961, p.315; Dumont, 1970, pp.1-162; Barnabas and Mehta, pp.1-20; Agarwal, 1965) pp.10-11.

${ }^{19}$ Kolenda (1978, p. 32) writes: "These four classes, called varnas, seem to have existed in Aryan society in ancient northern India.... It is generally agreed by scholars of ancient India that the varnas of Aryan society were functional groupings rather than closed endogamous birth-descent groups. That is, the original varnas were not jatis or castes, for there is evidence that people could and did change their varna identity. Furthermore, marriages between persons of different varnas took place and were allowed."

${ }^{20} \mathrm{By}$ focusing on varna divisions, I ignore much of the caste system's complexity. Summarizing this complexity, Kolenda (1978, p. 62) writes: "The institution of caste is composed on certain universal Hindu ideas. These include the Hindu pollution concept; the social units of jatis (endogamous large-scale descent-groups); the cognitive categories of 
description of a societal division of labor, the caste system was an institutionalization of that division: the caste system embodied rules that readily identified members of the various varnas, determined forms of interaction between them, and specified a gradation of social and legal rights according to varna. In the caste system, one's varna was indisputably determined for life by birth with the major division in the caste system between the Sudra and the other three varnas, the Brahmans, Kshatriyas, and Vaishyas. ${ }^{21}$ Reflecting their exclusion from the religious and social life of the community, the castes of the Sudra varna have sometimes been labeled the "exterior castes" (Hutton, 1961, Appendix A).

When it is said that the caste system is more rigid in one period or region than another, it is meant that the rules encompassed by the caste system took on a more extreme form. The more rigid the caste system, for instance, the more confined the interaction between members of different varnas: a continuum could be followed from restrictions on marriage to restrictions on the sharing of food to restrictions on any form of social interaction. The historical analysis that follows explores whether the development, perpetuation, and rigidity of the caste system concurred with the development, perpetuation, and strength of involuntary labor. And, if such a joint development occurred, did it correlate with the labor/land ratio?

\section{A. North India}

$\underline{\text { The Early Vedic Period }}^{22}$ The period from 1500 to 1000 B.C. is sometimes referred to as the

\footnotetext{
varnas (ranked classification of jatis); the associated concepts of jatidharma (religiously-given duties for jati members) and varnadharma (religiously-given duties for varna members); and the inter-jati local division of labor, such as the jajmani system, which makes a system of a multiplicity of bounded social units within a village or set of neighboring villages.”

${ }^{21}$ Dumont 1970, Appendix C; Mabbett 1970, p.33.

${ }^{22}$ References for this section include Rapson (1922, vol. 1, pp. 697-703), Lethbridge (1881, pp. 137-148), Morris and Stein (1961, pp.180-187), Mabbett (1970, pp.6, 13, 46), Sharma (1958, pp. 22-23, 26-41, 81), and Murdoch, (1977, p.vi).
} 
early Vedic period or the Rig Vedic period since most of what we know of this era comes from the earliest writings of the first two Vedas, the Rig Veda and the Atharva Veda. During this period, the Aryan tribes settled in the Indus and Ganges river valleys and continued to spread over northern India. Land was plentiful and population thinly spread. Agriculture was done by clearing an area, burning off the undergrowth and trees, and then growing crops not requiring water. Using "slash and burn" methods, the soil's fertility was depleted in a couple of seasons, forcing the primitive agriculturalists to move on. Wealth for the nomadic tribes mainly consisted of herds.

Without settled agriculture, a system of land grants could not be used to support a class of military servitors and priestly followers of the tribal kings. The texts for this period record no instance of a tribal king giving a land grant to his followers. Instead, tribute and booty from conquered peoples supported the tribal kings and their retinue.

The labor/land theory predicts that free land and free labor cannot coexist given a nonworking landowning class. Here we have free land, but without settled agriculture, a class of nonworking landowners has not developed. What about the existence and extent of involuntary labor and the caste system?

Male slaves hardly existed in the early part of this period. Towards the end of it, there are indications of an increasing number of slaves from recently conquered peoples. ${ }^{23}$ However, their activities were confined to domestic services for priestly or warrior masters; there is no evidence of slaves or serfs engaged in agricultural activities.

Given these conditions, the thesis of the paper would predict the absence of a restrictive

\footnotetext{
${ }^{23} \mathrm{~A}$ recently conquered group can be enslaved or enserfed without a corresponding change in the legal structure; since the oppressed group is outside of the society, no heed need be paid to a historical precedent of rules and rights applying to all members of society. Also refer to Engerman (1973) on this point.
} 
caste system. This, in fact, appears to be the case. Although the concept of varna is first mentioned towards the end of this period in the tenth book of the Rig Veda, there were no restrictions on marriage, the exchange of food and water, or any form of social interaction. Sudras were not considered impure and ideas of pollution stemming from contact with Sudras were absent. Sudras were referred to as independent peasants who participated in communal life.

$\underline{\text { The Later Vedic Period }}^{24}$ The later Vedic period, spanning 1000 B.C. to 600 B.C., is described by the later hymns of the Rig Veda along with other collections in Vedic literature such as the Samhitas, the Brahmanas, the Upanisads, and the epic Mahabharata.

Entering this period, land continued to be plentiful. Indeed, the Aryans’ domain increased as they spread throughout all of northern and parts of central India. (Aryan should perhaps be replaced by North Indian at this point, since the “Aryan” tribes had incorporated peoples descended from the original Indians as well.) Agriculture continued to be of the slash/burn variety and the primary productive activities were pastoral. In the Vedic Samhitas and Brahmanas, references are made to tribute in kind paid to the king. There is, however, no specific discussion of revenue from crops as opposed to domestic animals or other kinds of wealth, and there is no distinction between the revenue from subjects and the tribute exacted from conquered peoples. Thus, at the beginning of this period, an established system of revenues from the land to support servitor and priestly followers had not yet developed.

During this period, however, the Aryans’ way of life as nomadic agriculturalists and herdsmen changed. Settled agriculture spread across the Gangetic plains, accompanied by a growth

\footnotetext{
${ }^{24}$ References for this section include Rapson (1922, vol. 1, pp.697-703), Sharma (1958, pp.41-46. 48-57, 63-81), Lethbridge (1881, pp.149, 152), Goshal (1973, pp.4-9), Mabbett (1970, pp.46-48), Morris and Stein (1961, pp. 31, 180), and Agarwal (1965, pp.10-11).
} 
in individual land ownership by tribal kings; towards the end of the Vedic period, references appear of land given as gifts to the Kings' followers. The thesis of this paper predicts that with abundant land and the development of a nonworking landowning class, agricultural involuntary labor and a restrictive caste system would develop. This appears to be the case.

At the beginning of this period, Sudras independently owned cattle and were free from serving others for a livelihood. Yet, based on religious texts during the late Vedic period, the Sudra varna came to include those who were dispossessed of their cattle. Towards the end of the Vedic period, Sudras are described as slaves on individually owned lands, and references are made to the practice of ruling chiefs giving away lands along with slaves attached to this land.

The development of the caste system mirrored the transformation of the Sudra from free peasant to agricultural slave. Entering this period, Sudras did not suffer from social disabilities. They participated in communal ceremonies and the functions of the state: there are references to the Sudras' representation on a council of high functionaries. The Mahabharata relates that all the men of the tribe were trained to defend their crops and cattle. Thus, the Sudra had the right to bear arms. Initiation of young people into religious education and the adult Hindu community, the Upanayana (similar to the Jewish bar mitzvah), was open to all varna. According to texts, a person's varna and social status were a function of qualities and actions, not birth. Indeed, at the beginning of this period, there are examples of sages or priests whose mothers were Sudras.

Yet, during this period, a process began and grew to exclude the Sudra from communal life. Rituals increasingly depicted an evolving low status of the Sudra. For instance, although Sudras could participate in funeral rites, the sepulchral mound had to be lower in height than those for members of the other varnas. Political life became less and less the domain of the fourth varna. 
Although marriages occurred between Brahmans, Kshatriyas, and Sudra women, Sudra wives were looked upon with less respect, and marriages between Sudra men and higher varna women were prohibited.

As the end of the period approached, the association of impurity with the Sudra began to develop. For specific ceremonial activities, there were prohibitions against contact with or even sight of the Sudra. Finally, in the Srautasutras, it is stated that the Upanayana could "only bear fruit in the case of those who are not Sudra and don't indulge in wicked activities.” It is also the Srautasutras that first explicitly described the use of Sudras as agricultural slaves.

600 B.C. to 200 B.C. ${ }^{25}$ During the next period, territorial monarchies were firmly established. These kingships, mostly present in the Ganges area, were constantly at war with their neighbors, each striving to build up an empire. By 300 B.C., the Mauryans came to control most of India down to the Vindhyan range. Warrior and priestly classes supported these kingdoms in exchange for land grants; there are many references to land assignments to warrior servitors and Brahmans.

As the labor/land ratio theory would predict, accompanying the abundant land and large class of warrior and priestly landowners was involuntary labor on an extensive scale. There are references to two types of agricultural laborers, dasas (translated as slaves) and kammakaras. Many references appear about the type of food dasas should be fed, the fact that they were distinguished by a shaved head with a knot, and that they were often running away from their masters. Kammakara is translated as "hired laborer." However, during this period, dasas and kammakaras appear to have been functionally equivalent. Kammakaras and dasas were assigned the same work, given the same

\footnotetext{
${ }^{25}$ References for this section include Goshal (1973, pp.7-10), Mabbett (1970, p. 49), and Sharma (1958, pp.85-104, 16
} 
type of food, received the same punishments, and were considered the property of the landowner.

The kammakara could be beaten, seized, or bought. The Sudras were the dasas and the kammakaras. $^{26}$

During most of the later Vedic period, the religious texts only implied that Sudras comprised the servile class. In contrast, the religious law books of this period, such as the Dharmasutras, explicitly stated that the duty of the Sudra was to serve the first three varna. Indeed, the term used for the first three varna meant "one who is free."

In addition to singling the Sudra out for slavery, caste system rules of social distance and disabilities were promulgated against the fourth varna. In the Dharmasutras, the notion that food becomes impure when touched by a Sudra was introduced for the first time. The legal system of the period unambiguously stated the lowly status of the Sudra. Sudras were excluded from the Vedic rituals. They were subjected to corporal punishment even for minor offenses. Wergild, according to varna, emerged. According to the law of Gautama in the Dharmasutras, if a Brahman abused either a Kshatriya or a Vaishya, he would have to pay a fine. Yet, no punishment would follow if the abused were a Sudra. If a Sudra abused a twice-born, harsh and generally corporal punishment was specified. If a Sudra committed adultery with a woman of twice-born status, the punishment was death.

Along with rules establishing the lower value of a Sudra's life were rules to distinguish the Sudra from the higher varna. Forms of salutation and positions were specified that Sudras were to assume when in the company of higher varna persons.

107-121, 141-145, 160-167).

${ }^{26}$ It is interesting to note that although landowners could exchange slaves, they could not sell them. Just as the prohibition on agricultural labor's freedom to move is hypothesized to have been a response by landowners to the 
Rules were also instituted to help perpetuate the Sudras' servile status. The Sudra lost all political representation. The Apastamba Dharmasutra states that Sudras were to be excluded from the Upanayana, hence all literate education. The Sudra lost the right to carry arms, even in an emergency.

$\underline{200 \text { B.C. to A.D. } 200^{27}}$ In the time period 200 B.C. to 200 A.D., the Hindu kingdoms covered extensive portions of India. Concurrently, successive waves of invaders such as the Bactrian Greeks, Sakas, Parthians, and Kusanas, who flowed into India from the northwest, besieged the Hindu kingdoms. Moreover, it was a time of powerful Buddhist kingdoms. The Manava Dharmasastra, or the laws of the priest Manu, provides information for this period on the scarcity of labor, the extent of involuntary labor, and the rigidity of the caste system.

A system of land grants was in operation as there are references to land grants given as remuneration to servitors. The combination of large stretches of land to protect along with a quickened rate of foreign incursions likely escalated the need for military servitors. A picture is painted of the Hindu kingdoms spread thin and their military resources strained.

At the same time, the relative size of the agricultural laboring class to till their lands may have decreased; the "heretical” Buddhist kingdoms likely lured some of the agricultural laborers away from Hindu landowners. Indeed, several observations suggest a shortage of agricultural labor to work the lands of the Hindu landowners. There are descriptions of agricultural dasas and kammakaras shackled with fetters and chains to prevent them from running away while being severely tortured to induce them to work. At the same time, the share of the master's land that serfs

scarcity of labor, the prohibition on their sale may have been similarly motivated. (Also refer to point 10 in "Part VI: Caveats and Directions for Further Research.”)

${ }^{27}$ References for this section include Lethbridge(1881, pp.153-155), Mabbett (1970, p. 61), Sharma (1965, pp.176-178, 
could use appears to have increased under Manu's laws: in the Arthasastra, pertaining to the period before Manu's time, involuntary agricultural labor was allocated only one-third or one-fourth of the produce; in Manu, one-half could be retained. Conceivably, the higher remuneration was in reaction to increased incidents of agricultural Sudras running away.

Accompanying these circumstances was the most extreme caste system in the history of north India. The predominant status of the Sudra was that of an agricultural dasa or kammakara. Manu specified that the eternal destiny of the Sudra was to serve the twice-born. The Manava Dharmasutra essentially repeated the caste dictums of the previous texts, except new rules appear that further downgraded and identified the Sudra. Additional untouchability conditions were stipulated. The judicial system further lowered the status of the Sudra as Manu's laws took an unusually cruel bent, prescribing torturous punishment even for minor offenses by the Sudra. In addition to a prescribed dress, form of address, and conduct to identify the Sudra, now even the name given a child was to designate the child's varna. A Brahman's name was to denote something auspicious, a Kshatriya’s, power, and a Sudra's, something contemptible.

$\underline{200 \text { A.D. to } 700 \text { A.D. }}{ }^{28}$ During the period 200 A.D. to 700 A.D., the Gupta Empire was in force, extending over much of northern and central India. One gleans relevant information for this period from the Hindu law books of Yajnavalkya, Kamandaka, Narada, Brhasapati, and the Santi Parvan. As all of the respective lawgivers are thought to have resided in the north, these writings only describe conditions existing in north India. Supplementing these writings are the observations of Chinese pilgrims who traveled through northern India towards the end of the Gupta era. ${ }^{29}$

191-197, 199-211, 217-218), and Agarwal (1965, pp.10-11).

${ }^{28}$ The references in this section include Sharma (1958, pp.221-225, 228-242, 245-268, 271-283).

${ }^{29}$ Other relevant texts are the law books of Visnu and Katyayana and technical books such as the Amarakosa of 
A prominent feature of the Gupta era is an increasing density of population in north India. The writings of the Gupta period never describe large land grants, such as those of the Mauryan Empire and before. Rather, there are references to plots of land no larger than seven acres. According to a survey of land grants given by the rulers in Gujarat, the average grant did not exceed two or three acres. Epigraphical evidence shows that in Bengal it was impossible to obtain even a plot as small as one acre. Instead, the land had to be purchased at several different places. In discussing inheritance laws, Manu and the law books preceding Manu, never mentioned the partition of landed property. The Gupta period lawbooks of Narada and Brhasapati discuss this for the first time.

Writings of this period suggest that with the increase in population density, involuntary agricultural labor diminished, and that by the end of the seventh century many of the Sudra in north India were free peasants. Yajnavalkya wrote that no one could be reduced to slavery without his consent. The law book of Narada describes for the first time a ceremony for the emancipation of slaves. Another text of this period asserts that it is wrong to sell persons. The law books of the seventh century A.D. use the term peasant when referring to the Sudra, and the Chinese pilgrim Hsuan Tsang also described the Sudras as peasants.

That landowners no longer needed to rely on involuntary labor to reap a rent is further indicated by the removal of restrictions on the Sudra's entry into trade and craftsmanship. Indeed, the priest Brhasapati counted crafts and trade among the normal occupations of the Sudra, although a heavier tax was levied against Sudra craftsmen than against others.

The thesis of this paper suggests that the establishment of involuntary labor by a landowning 
class, in response to a low labor/land ratio, co-evolved with a caste system to provide the legal and social framework to justify, enforce, and perpetuate involuntary labor. Conversely, this hypothesis predicts that with slavery and serfdom waning, the rigidity of the caste system should diminish as well. In general, this turns out to be the case.

In north India, certain castes within the Sudra varna, whose jobs were considered unclean, continued to suffer the extreme legal and social disabilities once countered against the agricultural Sudra. The occupations of these castes included cleaning streets, executing criminals, and working in cremation grounds. Gradually, a distinction evolved in the religious law books of the Gupta era that distinguished the agricultural Sudra (agricultural work was now considered clean) from the Sudra castes who performed unclean work. The following refers only to the mass of Sudra engaged in agriculture.

Texts for the two periods preceding the Gupta era promulgated caste rules and associations that emphasized the lowly status of the Sudra. These included laws prescribing severe and often corporal punishments for Sudras who offended twice-born individuals, but no punishment or meager punishments for higher varna members who abused Sudras; portrayals of the Sudra as godless, hence unworthy of participating in religious ceremonies; and associations of the Sudra with impurity accompanied by rules of untouchablity. Such rules and associations were increasingly undermined during the Gupta era.

Yajnavalkya accepted the principle of legislation according to varna, but ignored Manu’s severe measures directed against the Sudra. In legislating punishment for assault, Yajnavalkya eliminated all varna distinctions. Later on, the Santi Parvan stipulated the same punishment for a Kshatriya, Vaishya, or Sudra for killing a Brahman. The Chinese traveler Fa-hsien wrote that 
criminals in central India were fined according to the seriousness of their offense. This suggests that varna distinctions were absent. Epigraphical evidence from western India from the sixth century shows no varna distinctions with respect to punishment for defamation, assault, and injury. The Sudra of Gupta times enjoyed legal protection from abuses by members of higher varnas. Unlike the legislation of the past in which a Brahman would go scot free if he abused a Sudra, the offending Brahman in the Gupta era had to pay a fine. Nor did the law books of this period set up a system of wergild according to the varna of the victim.

No mention is made of the severe punishment prescribed earlier on for a Sudra who committed adultery with a woman of twice-born status. Although considered unwise, Brahmans and Kshatriyas married Sudra women. The Sudra could also participate in religious ceremonies, such as the sraddha rites, heretofore the exclusive domain of the higher varna. According to the Santi Parvan, all varnas were allowed the right to perform sacrifices. Untouchability conditions formerly lodged against the agricultural Sudra lessened considerably. The twice-born could now accept water from the agricultural Sudra. In short, legislation during the Gupta era moved towards putting the Sudra's life on a par with the lives of higher varna.

What about laws to enforce the enslaved status of the Sudra? Such rules identified the Sudra by foisting on him a distinct form of dress, behavior, and name. Although information on dress is lacking, social customs of the Gupta era were delineated less according to varna divisions. Furthermore, traditional Sudra names incorporating the word slave (dasa) were no longer limited to Sudras. For instance, the chief of a feudatory of Candra Gupta III was called Maharaja Visnudasa. As for rules to perpetuate the enslaved or enserfed status of Sudras, Yajnavalkya and Kamandaka repeat the old dictums advising against the appointment of Sudras for government 
positions. Yet, later on, the Santi Parvan established a council of eight government ministers, three of whom were to be Sudra. The Santi Parvan also opened education to the Sudra; members of all varnas should hear the Veda. It further stated that a person should acquire knowledge even from a Sudra; references are made to educated Sudras. Finally, the Santi Parvan granted the Sudra the right to bear arms.

These changes in the religious-legal structure of the time were accompanied by the development of reforming creeds (Vaisnavism, Saivism, and Tantricism) which more or less gave the Sudra an opportunity of attaining religious equality with the other varna. Hinduism, in general, began to lay more stress on the deeds of a person rather than their birth: “...not birth, nor sacrament, nor learning, nor stock make one regenerate (twice-born), but only conduct.”30

The historical analysis of north India, summarized in Table 1, sketches a general correlation between the labor/land ratio and the joint development, perpetuation, and extent of involuntary labor and the caste system as it pertained to the agricultural Sudra. It supports the thesis that the labor/land ratio was a central force behind the joint evolution of involuntary labor and the caste system.

\section{B. South India}

In striking contrast with the north, land remained abundant in the south. Inscriptions throughout the period 1000 through 1500 A.D. relate that almost every form of service to the king was remunerated or insured by a land grant (Appadorai, 1936, p.258). As late as the early twentieth century, a British census report commented on the abundance of arable land in south India (Kerala) and on the desirability for additional population growth:

\footnotetext{
${ }^{30}$ Quote from the Santi Parvan cited in Sharma (1958, p. 276).
} 
If then there be no extraneous conditions to disturb the pursuits of life... it may be said that as regards the development of population strength, the future is full of hope. (Census of India, Travancore, Part III, vol. 23, 1911 (Trivandrum, 1912) pp.87-88)

According to the thesis of this paper, the persistence of abundant land in the south should have fostered the joint continuation of involuntary labor and a rigid caste system.

Numerous epigraphical inscriptions originating from various southern localities confirm the large scale existence of serfdom all over south India from the twelfth century through the fifteenth century A.D. ${ }^{31}$ In describing the period 1000 through 1500 A.D. of south India, Baden-Powell writes: “The slave of the middle ages when he was connected with agriculture was a territorial slave attached to the land.”32

The serfs of south India were comprised of the Sudra. The writings of Duarte Barbosa, a Portuguese traveler who recorded his observations of India in 1518 A.D., indicate that involuntary labor composed of members of the Sudra varna continued into the sixteenth century in the south. In describing one caste of the Sudra varna in south India, the Thiyas, Barbosa wrote: "The most part of them are slaves bound to the lands of the Nayres [an upper caste in south India] to whom they are assigned by the king that they [the Nayres] may live and support themselves by the labour of these men.”33 About another Sudra caste, the Betunes, Barbosa wrote: “[they] are slaves of the Kings and the Nayres and pass their lives in poverty."34

In fact, enserfment of the Sudra in south India continued up through the nineteenth century.

\footnotetext{
${ }^{31}$ Sources cited in Appadorai (1936, pp.253-8, 318) document inscriptions dating from the 12th, 13th, and 15th centuries A.D. that describe agricultural serfdom in Belur, Coorg, Travancore, Tanjore, Sorab, Sagar, as well as Canarese inscriptions.

${ }^{32}$ Baden-Powell (1892, Vol. III, pp.121-22), cited in Appadorai (1936, pp. 257-58).

${ }^{33}$ D. Barbosa, The Book of Duarte Barbosa: An Account of the Countries Bordering on the Indian Ocean and their Inhabitants, Vol II, translated from the Portuguese text by Mansel Longworth Dames (London: Hakluyt Society, 19181921), p. 60, cited in Appadorai, p. 257.

${ }^{34}$ Barbosa, p.65, cited in Appadorai (1936, p.257).
} 
In his report on exterior castes for the 1931 Census of India, Hutton wrote of the south Indian situation: "The exterior castes are generally derived from various classes of cultivating serfs who until recently were tied to the soil”. ${ }^{35}$ Kumar (1965) cites many references documenting various forms of slavery and serfdom in south India throughout the 19th century. In describing the evolving stance of the British towards agrestic servitude in the south, Kumar notes “...conditions of bondage persisted even into the twentieth century.”

By the twentieth century, serfdom was outlawed in the south. Yet, the reason behind its long life in southern India may not have died out: serfdom may still have been more profitable to south Indian landowners in the early twentieth century than free labor. For instance, in the early 1930's, the landowning caste in the southeastern state of Ramnad, the Kallar, established a set of rules clearly aimed at preventing two castes of the Sudra varna, the Adi-Dravida and Devendrakula Velalars, from entering into contractual labor arrangements with landowners, or of farming their own land. The Kallar also proclaimed caste rules to enforce and perpetuate this condition, illustrating the intimate connection between the institution of noncontractual labor and the institution of caste rules. Among the rules put forth by the Kallar, were the following:

—The Adi-Dravidas and Devendrakula Velalars should not wear clothes below the knees.

— No Adi-Dravida shall be allowed to have his hair cropped.

—-Their children should not ... [become] literate or educated.

- The children should be asked only to tend the cattle of the Mirasdars (landowners).

— Their men and women should work as slaves of the Mirasdars in their respective Pannais (land plots).

- They must sell away their own lands to Mirasdars of the village at very cheap rates, and if they don't do so, no water will be allowed to them to irrigate their lands.

- They must work as coolies from seven a.m. to six p.m. under the Mirasdars and their wages shall be for men Rupees 0-4-0 per day and for women Rupees 0-2-0 per day.

Other rules were aimed at further distinguishing members of these two Sudra castes. ${ }^{36}$

\footnotetext{
${ }^{35}$ Hutton (1961, pp. 206-7). Also refer to B. H. Baden-Powell (Oxford, 1892, vol. III, pp.121-122).

${ }^{36}$ These rules are quoted in Hutton (1961, pp.205-6).
} 
It is unlikely that such rules had any standing in the 1930's judicial system of Ramnad, although the Kallars responded to their disregard by destroying property belonging to exterior castes (Hutton, 1961, pp.206-7). Nevertheless, the rules provide insight into the thinking of the landowning castes and to what is hypothesized to be the primary reason behind the joint development and perpetuation of tied labor and the caste system.

\section{Measures of Caste Rigidity and the Labor/Land Ratio across Regions}

The history of northern and southern India sketched above is broadly consistent with this paper's thesis: as land became scarce in the north, involuntary labor decreased and caste rules that had helped subjugate the agricultural Sudra subsided. The historical evidence suggests that the persistence of abundant land in south India (fostering a condition wherein tied labor was more profitable than free labor) may have contributed to the persistence of a stronger caste system in the south than the north. A further test of the hypothesis is possible by linking cross-sectional data on caste rigidity with British census data on regional population/land ratios.

Using field work conducted at the beginning of the 1950's, along with data from early twentieth century research, the anthropologist McKim Marriott (1965) examined variations in the rigidity of the caste system across five regions of India: Kerala, Coromandel, Upper Ganges, Middle Indus, and Bengal Delta (see Figure 1). Marriott ranked each area according to the degree of consensus on the hierarchy of castes, the extent of delineation of hierarchy by ritual, and the extent of limits on social interaction between high and low castes.

According to this paper's hypothesis, caste rigidity and the labor/land ratio should be inversely correlated across these regions: those areas with the lowest labor-to-land ratios should 
have experienced tied labor to a greater extent and for a longer period of time as well as a more rigid caste system to support the institution of tied labor. The analysis pursued here assumes that the ranking of the regions' labor-to-land ratios in the early twentieth century reflects their earlier relative positions. As long as this is true, an inverse relationship should occur between the labor/land ratio and the rigidity of the caste system, even though slavery and serfdom were outlawed by this time. The inverse relationship would reflect the inertia of the caste structure to change, even though the initial reason for its existence had ceased. This is consistent with a theme in institutional economics that cultural endowments change slowly while institutional arrangements may be changed more quickly.

The five areas of Marriott's analysis ranked in descending order of caste rigidity are Kerala, Coromandel, Upper Ganges, Middle Indus, and Bengal Delta. ${ }^{37}$ My hypothesis would then predict that the labor-to-land ratio in the early twentieth century would have been lowest in Kerala, second lowest in Coromandel, followed by Upper Ganges, Middle Indus, and with the highest ratio, Bengal Delta.

To obtain population-to-land ratios for areas that closely approximate the regions used in Marriott's analysis, I used statistics from the 1911 Census of India. ${ }^{38}$ In the Census data, the areas Kerala and Coromandel, used in Marriott's study, are subsumed in the pre-Independence Census division Madras Presidency and States. Census information is available, however, on the population-to-land ratio of western Madras and States relative to eastern Madras and States. Western Madras and States corresponds to Marriott’s division, Kerala, which includes the provinces

\footnotetext{
${ }^{37}$ Within south India, Kumar (1965) also found the caste system and agrestic servitude more widespread and severe in Malabar (part of Kerala) than in Coromandel.

${ }^{38}$ Census of India, 1911, General Report, pp.12-27.
} 
Travancore, Malabar, and Cochin; eastern Madras and States corresponds to Coromandel.

Table 2 lists the population-to-land ratio (expressed in persons per square mile) for each region along with the corresponding caste ranking from Marriott's analysis; 5 denotes the most rigid caste structure and 1, the least. With the notable exception of the Middle Indus region, the lower the population-to-land ratio, the stronger the caste system: Kerala has the lowest population-to-land ratio and the strongest caste system; Bengal Delta the highest population-to-land ratio and the weakest caste structure.

\section{A. Effective Labor-to-Land Ratios}

Ideally, regional caste rigidity should be related to the effective labor-to-land ratio; the denominator of the ratio should measure the quantity of arable land, rather than the total quantity of land.

A number of factors affect the extent of arable land. These include surface characteristics of the land (is it broken or flat?), the rain level, and how the rain level is dispersed over the year and the region. The following information, derived from the 1911 and 1891 Censuses of India, gives a feel for what the relative effective labor-to-land ratios were among the five areas of Marriott’s analysis. ${ }^{39}$

According to the early British censuses, the population in the Bengal Delta region, which had a population density almost twice that of Kerala or Coromandel, was concentrated along the river. The rain level was second highest of the five regions.

The Upper Ganges region, with the second densest population, was generally fit for cultivation except for broken country in its northwestern and southern parts. The rainfall was

\footnotetext{
${ }^{39}$ This information was derived from the Census of India, 1911, General Report, (1914, pp.12-27, 82) and Census of 
copious, but variable; the 1911 Census comments that extensive irrigation aided cultivation.

Evidently, irrigation increased the amount of arable land from what it would otherwise have been.

The 1891 Census cites the correlation between the uncertainty of rainfall in this region and the probability of famine.

The Middle Indus region ranked two on the one-to-five scale of caste rigidity, yet it had the lowest population-to-land ratio. This is not such an anomaly, however, when the amount of arable land at that time is considered. Large parts of the Middle Indus region were unfit for cultivation. In the Himalayan region in the northeast, including the Simla Hills, the surface is broken. According to the 1911 Census General Report, only one-fifth of the area was fit for cultivation. The northwestern and eastern sections contained large desert areas that, according to the 1911 Census, were useless when not irrigated except for precarious grazing. (The 1911 Census also comments that irrigation could convert extensive tracts into fertile wheat fields. $)^{40}$ The region's rainfall was insufficient to support much cultivation, its average rainfall being the lowest of all five areas. The Middle Indus region had the most extensive irrigation system of all five regions and population density varied greatly with the existence of irrigation. In describing the nonpastoral areas of the Middle Indus region, the 1891 Census cites the great density of population on its arable portions. ${ }^{41}$ More generally, the 1891 Census comments that the central provinces of India "have generally been regarded as a field of immigration from the more densely peopled tracts of Bengal and the North West provinces.” 42

Turning to the South, almost all of Coromandel (the eastern portion of the Madras

India,_1891, General Report (1893, pp.9-41, 74).

${ }^{40}$ Census of India, 1911, General Report, p. 21.

${ }^{41}$ Census of India, 1891, General Report, p. 40. 
Presidency and States) was fit for cultivation. The rain level was similar to that of the Upper Ganges region, yet less variable, and the region depended less on irrigation than was true of the Upper Ganges region.

Finally, the region with the highest caste rigidity ranking, Kerala, also appears to be the region that was most uniformly suitable to cultivation. A Census report devoted to Travancore, the largest of the three states in Kerala, comments: "The rains come the year round and benefit the characteristic cultivation wherever and whenever they fall.”33 Heavy and generally abundant rainfall along with a uniform and healthy climate for cultivation characterized all of Kerala.

In summary, using the effective labor-to-land ratio, the Middle Indus region is less of an outlier from an otherwise inverse relationship between the labor/land ratio and the caste structure's rigidity. More generally, the inverse relationship is as strong or stronger using the effective labor-toland ratio, rather than the simple labor/land ratio, since the southern areas, where the caste system was strongest, were at least as favorable as if not more favorable to agriculture than the northern regions.

\section{B. Effective Labor-to-Land Ratios in the 19th Century}

Since the caste structure at any given time likely reflects conditions prevailing in preceding time periods, it is of interest to know what the effective labor-to-land ratios of the respective regions were before Marriott's twentieth century measurements of caste rigidity. Two factors indicate that the difference in the effective labor-to-land ratio between the south and north was probably larger in the nineteenth century than in the twentieth century.

\footnotetext{
${ }^{42}$ Census of India, 1891, General Report, p. 41.
} 
Both the 1911 and 1897 Censuses state that regional population growth was inversely related to population density. ${ }^{44}$ This suggests that the difference between the population-to-land ratios of the south and north may have been greater preceding the twentieth century.

The other factor that suggests a larger south-north difference in effective labor-to-land ratios prior to the twentieth century is the extent of irrigation by region. Much of the existing irrigation in 1911 was done around the turn of the century or shortly before. ${ }^{45}$ The 1911 Census does not provide information on the extent of early twentieth-century irrigation in the Bengal Delta region. However, of the five areas, the Middle Indus region had the most extensive system, followed by the Upper Ganges region. Coromandel had some irrigation, although not to the extent of the Upper Ganges region, and Kerala did not have any irrigation at all. A plausible assumption is that the proportion of arable land in the south was greater relative to the north before the twentieth century than afterwards, when irrigation increased the northern regions' arable land proportionately more than the arable land of the south. Both the information on population growth and the extent of irrigation suggest that prior to the twentieth century, the effective labor-to-land ratio of the south was even lower relative to that of the north.

\section{Caveats and Directions for Further Research}

The evidence presented in this paper supports the thesis that the caste system and involuntary labor were joint responses by a nonworking landowning class to a low labor/land ratio in which the rules of the caste system supported the institution of involuntary labor. While enticing, there are

\footnotetext{
${ }^{43}$ Census of India, 1911, Travancore, p. 88.

${ }^{44} 1891$ Census, p. 74; 1911 Census, General Report, p. 82.

${ }^{45} 1911$ Census, p. 27.
} 
several caveats that suggest intriguing future forays for scholars of involuntary labor.

(1) A major caveat of this paper's conclusion concerning the historical severity of the caste system in southern versus northern India is that not only was south India less affected than north India by Aryan influences, but it was also less affected by Muslim influences that may have moderated the caste system and agrestic servitude in the north. Kumar (1965) has documented extensive regional variations in the caste system and the extent and nature of agrestic servitude within south India. One could control for the effect of Muslim influences by examining whether variations in the caste system and involuntary labor as described by Kumar varied according to the labor/land ratio across detailed regions within south India. Information presented in this paper concerning caste rigidity and the labor/land ratios of Kerala versus Coromandel suggests that the relationships described in this paper may indeed hold across detailed regions within south India.

(2) The longitudinal analysis of this paper focuses on only one aspect of the caste system: the subjugation of the agricultural Sudra. It ignores other important features of the caste system such as the occupational substratum of the Sudra caste category whose work entailed the most pervasive contact with blood, death, and dirt (i.e. the Tchandalas) and, more generally, the myriad of endogamous groups (jatis) within any caste category (varna). It is also not apparent that the labor/land ratio would elucidate these intricate and numerous aspects of the caste system.

(3) Related to the second point, other researchers of the economics of the caste system may find that caste rigidity is a better variable to work with (as was pursued in the cross-sectional analysis) than the subjugation of the Sudra. The Sudra varna is an imprecise category with exceptions. Moreover, coerced labor included members of the "fifth varna," outside the caste system, which would include tribals. 
(4) Slavery and serfdom are lumped together in this paper. Kumar (1965) describes various forms of agrestic servitude that existed in South India. A direction for future research is to examine separately the relationships of slavery and serfdom (as well as Indian institutional variations within these broad categories as described by Kumar) to the labor/land ratio and the caste system.

(5) Research on the economics of the caste system could also benefit from scholarship that delves into the complexity of social arrangements in traditional agricultural labor including the difference between wet and dry farming and the use of coerced labor (Ludden, 2005).

(6) As noted by Domar (1989, p. xvii), the pace of the dissolution of involuntary labor as a function of the labor/land ratio is greatly affected by particular institutional arrangements such as whether the master could change at his discretion the serf's land allotment. A direction for future research is to bring into the analysis the different types of land arrangements and institutional arrangements that existed across regions of India.

(7) The history of institutional arrangements governing human property rights could be examined in countries other than India whose cultures were exposed to Hinduism.

(8) My analysis assumes a two-factor (land and labor) closed economy. Future researchers on the economics of the caste system could expand their focus to include the role of capital, the international migration of labor, and international trade. ${ }^{46}$

(9) My analysis is static: I relate the labor/land ratio to the state of the caste system and involuntary labor at particular times in history. Future research on the economics of the caste system, perhaps armed with better data, could pursue a more evolutionary approach that incorporates

\footnotetext{
${ }^{46}$ For an example of an analysis of the economics of property rights in people in the context of an open economy, refer to Feeny (1989). His study also illustrates third-party intervention in the dismantling of involuntary labor, discussed in point 10 of this section.
} 
insights from the institutional economics literature as exemplified in the works of Hayami and Ruttan (1971), Davis and North (1971), North (1981, 1990), Ruttan and Hayami (1984), and Feeny (1988). In terms of that literature, this paper's presentation of the historical development of the caste system is an argument about the creation of cultural endowments to support a particular system of property rights. A tenet of the institutional economics literature is that cultural endowments generally change very slowly. An issue for future work is a consideration of the effect of this inertia on the relationships among the labor/land ratio, involuntary labor, and the caste system. ${ }^{47}$ Path dependency is another insight from the institutional economics literature that future analysts may want to consider. ${ }^{48}$

(10) This analysis treats the labor/land ratio as exogenous. An intriguing line for further research would be to examine the relationship between the caste system and fertility.

(11) Engerman (1973, p. 61) notes that included in the costs of enforcing slave labor is "the maintenance of cartel stability to prevent competitive bidding for labor leading to benefits for the workers...” Examining the relative cohesiveness among members of the elite castes over time and across regions in India and its responsiveness to the labor/land ratio is an issue for further research. ${ }^{49}$

(12) Domar $(1970,1989)$ hypothesized that a rise in population with a given quantity of land should, ceteris paribus, lower labor’s marginal productivity and the market wage. The landowning class could then reap a rent simply with the aide of market forces, without the costs associated with

\footnotetext{
${ }^{47}$ In fact, this inertia is "used" in the analysis presented in Part V.

${ }^{48}$ Path dependency suggests that regardless of the reasons for the inception of a particular institution, there are factors that promote its persistence as, for instance, in the persistence of the QWERTY letter configuration for typewriters (David, 1985). On the perpetuation of slavery, Engerman (1973, p. 60) writes: “Although the inauguration of the system might be due to seemingly minor and incidental factors, once created the slave owning class has an incentive to avoid capital losses by perpetuating the system.”

${ }^{49} \mathrm{M}$. N. Srinivas (1957) wrote in the 1950's, “...the absence of powerful Brahman groups in the north has prevented the rising of an anti-Brahman movement ....”
} 
serfdom and slavery. However, Engerman $(1973,1992)$ argues that slavery and serfdom have features, beyond the market wage calculus, that make their voluntary dismantling by slave and serf owners unlikely. In particular, human property owners could ignore workers’ preferences concerning nonpecuniary aspects of work such as the amount of labor supplied, the location of work, the type of work, and the size of the establishment. This feature of involuntary labor facilitated and maintained certain types of agricultural production such as the large-scale plantation. ${ }^{50}$ Thus, the dismantling of slavery/serfdom constituted a loss to owners not only of the financial investment in the individuals they owned, but also of their investment in a whole way of life and production made possible with involuntary labor. This may explain why the demise of slavery and serfdom has generally occurred through the intervention of parties other than the slave and serf owners (Engerman, 1992).

In south India, serfdom and slavery were outlawed despite their apparent continuing profitability, in accordance with Engerman's thesis that the owners rarely voluntarily dismantle property rights in people. In contrast, the available evidence suggests a voluntary demise of agricultural slavery and serfdom in north India (as a result, I argue, of an increase in the labor/land ratio). As Engerman notes, there are other forms of involuntary labor such as indentured servitude and more generally, debt bondage (Engerman, 1973, 1992). ${ }^{51}$ One possibility for the "quiet" demise

\footnotetext{
${ }^{50}$ With regard to the relationship between the ability of slave owners to ignore nonpecuniary worker preferences and their pursuit of certain types of production, Engerman (1992, p. 21) observes that after emancipation in the United States "Many ex-slaves preferred to avoid working on plantations producing sugar, cotton, and other gang-produced crops, and where possible, sought to become producers on land of their own.” He further notes (p. 22) that “...in areas where cane sugar came to be produced for the first time in the late 19th century, such as Peru, Hawaii, and Australia, the use of indentured labor was central to the plantation regime."

${ }^{51}$ Engerman (1992, p. 18) notes two ways in which debt bondage simulates features associated with slavery: “...the essence of debt peonage is that it bound individuals to a perpetual, or at the least long-term period of repayment. A second purpose of debt peonage would thus be to create continued negative wealth in order to force a higher labor input."
} 
of slavery and serfdom in northern India is that there were factors in northern India that facilitated the enforcement of human property rights with debt.

These issues raised by Engerman's research suggest two intriguing lines for further inquiry. One is the relationship between the labor/land ratio and the development of involuntary labor through debt bondage instead of slavery or serfdom. Another is the effect of changes in the labor/land ratio on industrial developments fostering third parties who promote the demise of slavery and serfdom as they compete with slave and serf owners for labor. ${ }^{52}$ An interesting question along these lines is how the British in India went from passive (and sometimes active) support of involuntary labor in south India to outlawing it.

\section{Conclusion}

India's caste system served, in part, to divide the Sudra, from the other three caste categories or varnas, and to depress the status of the Sudra while elevating that of the landowning Brahman and Kshatriya varnas. By providing a legal structure to justify, enforce, and perpetuate tied labor, caste rules facilitated the involuntary servitude of the Sudra.

If the caste system evolved to support slavery or serfdom, then the development, perpetuation, and strength of the caste system should have responded to the same forces that propelled the development, perpetuation, and extent of tied labor. This paper proposes that the labor/land ratio affected the joint development of involuntary labor and the caste system.

Longitudinal and cross-sectional data support this hypothesis: historical variations in the rigidity of the caste system over time and across regions correlate with variations in the labor/land ratio.

India’s caste system has generally been viewed as a cultural product of Hinduism. Such an

\footnotetext{
${ }^{52}$ Engerman's arguments also suggest examining the intensity of the opposition by slave and serf owners to the 36
} 
understanding fails to explain variations in the existence and rigidity of the caste system over time and across regions of India.

In response to the puzzle that initiated this exploration — why was the caste system strongest in the south where Aryan influences were the weakest? - the results of this study suggest that the answer may lie in the south’s much longer history of abundant arable land. 


\section{References}

Agarwal, Hanuman Prasad, The Caste and Its Consequences, Allahabad: Saraj Prakashan, 1965.

Allchin, Bridget and F. Raymond Allchin,_The Rise of Civilization in India and Pakistan, Cambridge: Cambridge University Press, 1982.

Ambedkar, B.R., Annihilation of Caste with a Reply to Mahatma Gandhi, and Castes in India: Their Mechanism, Genesis, and Development, Jallundar City, Punjab: Bheen Patrika Publications, 1968.

Appadorai, Angadipuram, Economic Conditions in Southern India (1000-1500 A.D., Madras: University of Madras, 1936.

Baden-Powell, B.H., The Land Systems of British India Being a Manual of the Land Tenures and of the Systems of Land Revenue Administration Prevalent in the Several Provinces, Vol. III, Oxford: 1892.

Barbosa, Duarte, The Book of Duarte Barbosa: An Account of the Countries Bordering on the Indian Ocean and their Inhabitants, Vol II, translated from the Portuguese text by Mansel Longworth Dames, London: Hakluyt Society, 1918-1921.

Barnabas, A. P. and S. C. Mehta, Caste in Changing India, New Delhi: The Indian Institute of Public Administration, 1965.

Bhatt, A. Caste, Class and Politics: An Empirical Profile of Social Stratification in Modern India, Monohar Book Service, 1975.

Census of India, 1891, General Report, London, 1893.

Census of India, 1911, General Report, London, 1914.

Census of India, Travancore, Part III, vol. 23, 1911, Trivandrum, 1912.

David, Paul A., “Clio and the Economics of QWERTY,” American Economic Review, vol. 75, May 1985, pp. 332-37.

Davis, Lance E. and Douglas C. North, Institutional Change and American Economic Growth, London: Cambridge University Press, 1971.

Domar, Evsey D. “The Causes of Slavery or Serfdom: A Hypothesis,” The Journal of Economic History, Vol. 30, March 1970, pp.18-32.

—, Capitalism, Socialism, and Serfdom: Essays by Evsey D. Domar, Cambridge: Cambridge 
University Press, 1989.

Dumont, L., Homo Hierarchicus: The Caste System and Its Implications, Chicago: The University of Chicago Press, 1970.

Engerman, Stanley, “Some Considerations Relating to Property Rights in Man,” Journal of Economic History, vol. 33, no. 1, March 1973, pp. 43-65.

—, "Coerced and Free Labor: Property Rights and the Development of the Labor Force," Explorations in Economic History, vol. 29, no. 1, January 1992, pp. 1-29.

Feeny, David, “The Demand for and Supply of Institutional Arrangements,” in Vincent Ostrom, David Feeny, and Hartmut Picht, eds., Rethinking Institutional Analysis and Development: Some Issues, Choices, and Alternatives, San Francisco: Institute for Contemporary Studies Press, 1988, pp. 159-209.

—, “The Decline of Property Rights in Man in Thailand, 1800-1913,” Journal of Economic History, vol. 49, no. 2, June 1989, pp. 285-296.

Gopalachari, K., Early History of the Andhra Country, Madras: University of Madras, 1941, pp.9098.

Goshal, U.N., The Agrarian System in Ancient India, Calcutta: Saraswat Library, 1973.

Gould, Harold, The Hindu Caste System, vol. 1, Delhi: Chanakya Publications, 1987

Gunther, John, Inside Asia, New York: Harper and Brothers, 1939.

Hayami, Yujiro and Vernon W. Ruttan, Agricultural Development: An International Perspective, Baltimore, The Johns Hopkins University Press, 1971; Revised Edition, 1985.

Hutton, J.H., “The Position of the Exterior Castes,” in J. H. Hutton, Caste in India, London: Oxford University Press, Third Edition, 1961, Appendix A, taken with some abridgement from Appendix I to Hutton's report in the Census of India, 1931.

Kolenda, Pauline,_Caste in Contemporary India: Beyond Organic Solidarity, Menlo Park, Calif.: Benjamin/Cummings Publishing Co. 1978.

Kumar, D., Land and Caste in South India, Cambridge: Cambridge University Press, 1965.

Lethbridge, Roper, A Short Manual of the History of India, London: MacMillan and Co., 1881.

Ludden, David. Early Capitalism and Local History in South India, Oxford University Press, 2005. 
Mabbett, I.W., A Short History of India, New York: Praeger Publishers, 1970.

Marriott, McKim, Caste Ranking and Community Structure in Five Regions of India and Pakistan, Poona, India: Deccan College Postgraduate and Research Institute, 1965.

Milner, Murray, Status and Sacredness: A General Theory of Status Relations and an Analysis of Indian Culture Oxford University Press, 1994.

Murdoch, J. Review of Caste in India, Rawat Publications, 1977.

Morris, Morris D. and Burton Stein, “The Economic History of India: A Bibliographic Essay,” The Journal of Economic History, Vol. 211961.

Nieboer, H.J., Slavery as an Industrial System, New York: Burt Franklin, 1971.

North, Douglass C., Structure and Change in Economic History, New York: W.W. Norton, Inc, 1981.

—, Institutions, Institutional Change and Economic Performance, New York: Cambridge University Press, 1990.

Possehl, Gregory L.,_Harappan Civilization: A Contemporary Perspective, New Delhi: Oxford \& IBH Pub. Co., 1982.

Rapson, E.J., editor, The Cambridge History of India, vol. I, Cambridge: Cambridge University Press, 1922.

Ruttan, Vernon, W. and Yujiro Hayami, “Toward a Theory of Induced Institutional Innovation,” Journal of Development Studies, vol. 20, no. 4, July 1984, pp. 203-223.

Sharma, Ram Sharan, Sudras in Ancient India: A Survey of the Lower Orders Down to Circa A. D. 500, New Delhi: Motilal Bararsidass, 1958.

Srinivas, M. N., “Caste in Modern India,” Journal of Asian Studies, Vol. 16, No. 4, 1957.

Wheeler, M., The Indus Civilization, Supplementary Volume to The Cambridge History of India, Cambridge: Cambridge University Press, 1968. 
Figure 1

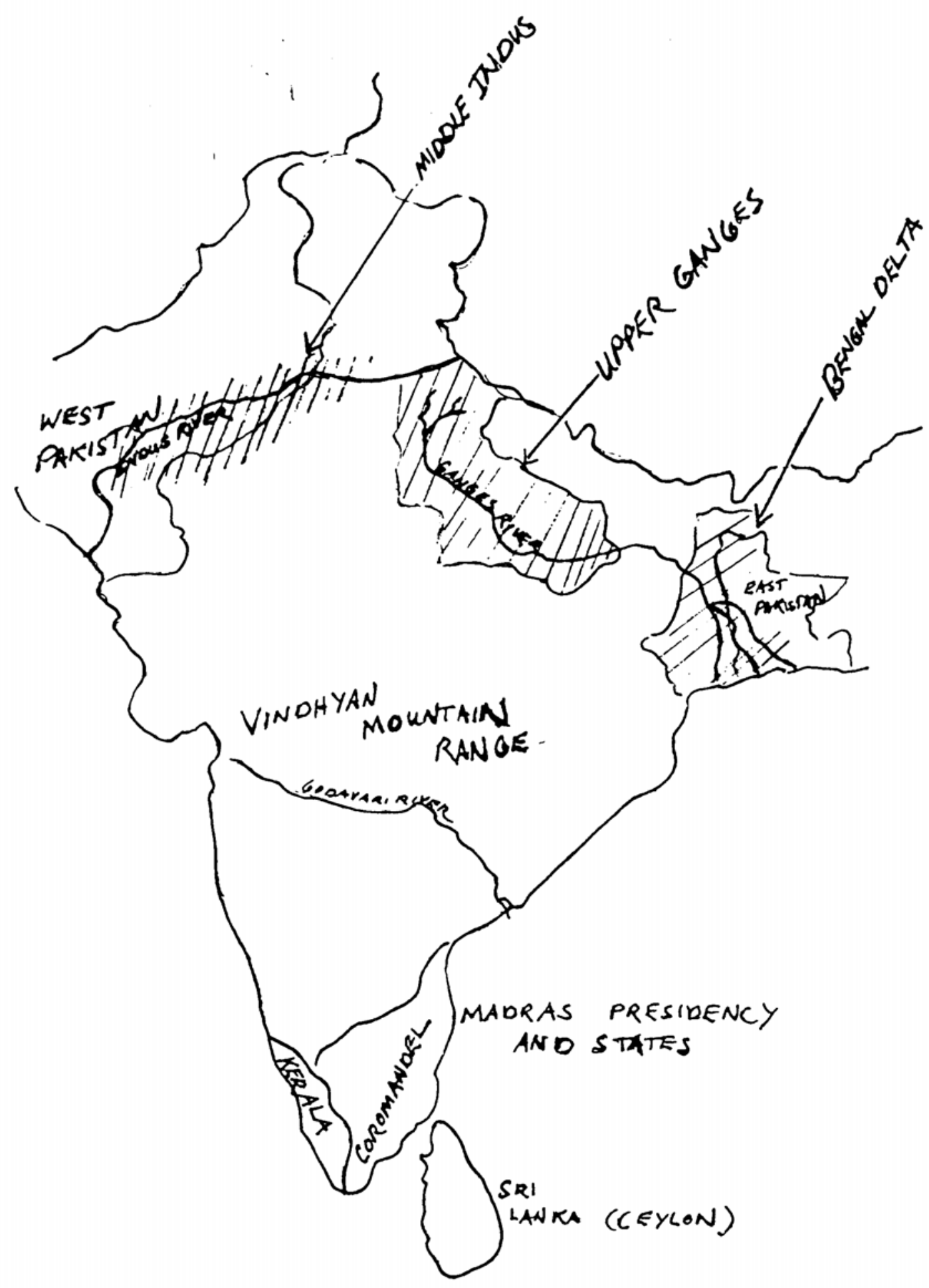


Table 1 Continued

\begin{tabular}{|c|c|c|c|c|}
\hline Period & Labor/Land Ratio & $\begin{array}{c}\text { Extent of Involuntary } \\
\text { Agricultural Labor }\end{array}$ & Rigidity of Caste System & $\begin{array}{l}\text { Sources of Relevant } \\
\text { Information }\end{array}$ \\
\hline $\begin{array}{l}600 \text { B.C. } \\
\text { to } 200 \\
\text { B.C. }\end{array}$ & $\begin{array}{l}\text { - Abundant land. } \\
\text { - Large class of warrior and } \\
\text { priestly landowners. }\end{array}$ & $\begin{array}{l}\text { • Extensive involuntary } \\
\text { agricultural labor. }\end{array}$ & $\begin{array}{l}\text { - Religious law books } \\
\text { explicitly state the servile } \\
\text { status of the Sudra. } \\
\text { - Notion that food becomes } \\
\text { impure when touched by a } \\
\text { Sudra is introduced. } \\
\text { - Sudras excluded from the } \\
\text { Vedic rituals. } \\
\text { - Wergild introduced. } \\
\text { - Sudra loses right to become } \\
\text { educated and to carry arms. }\end{array}$ & Dharmasutras \\
\hline $\begin{array}{l}200 \text { B.C. } \\
\text { to } 200 \\
\text { A.D. }\end{array}$ & $\begin{array}{l}\text { - Geographic spread of Hindu } \\
\text { kingdoms increases. } \\
\text { - Large stretches of land to } \\
\text { protect. } \\
\text { - Quickened rate of foreign } \\
\text { incursions escalating need for } \\
\text { military servitors. } \\
\text { - Relative size of agricultural } \\
\text { laboring class to till lands of } \\
\text { servitors likely decreased. }\end{array}$ & $\begin{array}{l}\text { - Extensive involuntary } \\
\text { agricultural labor. }\end{array}$ & $\begin{array}{l}\text { - Most extensive caste system } \\
\text { in history of north India. } \\
\text { - Religious texts state it is the } \\
\text { eternal destiny of the Sudra to } \\
\text { serve the higher castes. } \\
\text { - Caste dictums of previous } \\
\text { period intensify; additional } \\
\text { untouchability conditions. } \\
\text { - The judicial system further } \\
\text { lowers the Sudra’s status. }\end{array}$ & $\begin{array}{l}\text { Manava } \\
\text { Dharmasastra (Laws } \\
\text { of Manu) }\end{array}$ \\
\hline $\begin{array}{l}200 \text { A.D. } \\
\text { to } 700 \\
\text { A.D. }\end{array}$ & $\begin{array}{l}\text { - Increasing population density } \\
\text { of north India. } \\
\text { - Only small land grants given } \\
\text { by rulers. } \\
\text { - Partition of landed property } \\
\text { in inheritance laws first } \\
\text { discussed. }\end{array}$ & $\begin{array}{l}\text { - Involuntary agricultural labor } \\
\text { diminished. } \\
\text { - A ceremony for the } \\
\text { emancipation of slaves is } \\
\text { described for the first time. } \\
\text { - Restrictions on the Sudra's } \\
\text { entry into trade and } \\
\text { craftsmanship removed. }\end{array}$ & $\begin{array}{l}\text { - Caste distinctions eliminated } \\
\text { for various crimes. } \\
\text { - The Sudra can participate in } \\
\text { religious ceremonies. } \\
\text { - They gain the right to } \\
\text { education, political } \\
\text { representation, and to carry } \\
\text { arms. }\end{array}$ & $\begin{array}{l}\text { Lawbooks of } \\
\text { Yajnavalkya, Narada, } \\
\text { Brhasapati, and Santi } \\
\text { Parvan; writing of } \\
\text { Chinese pilgrims. }\end{array}$ \\
\hline
\end{tabular}




\begin{tabular}{|c|c|c|c|c|c|}
\hline \multicolumn{6}{|c|}{ Table 2: Caste Rigidity and Population to Land Ratios } \\
\hline $\begin{array}{l}\text { Marriott's regional } \\
\text { classifications }\end{array}$ & $\begin{array}{c}1911 \text { Census } \\
\text { Divisions (Pre- } \\
\text { Independence British } \\
\text { provinces and } \\
\text { feudatory states) }\end{array}$ & $\begin{array}{l}\text { Population to land } \\
\text { ratio: persons per } \\
\text { square mile }\end{array}$ & $\begin{array}{l}\text { Caste ranking: } 1 \text { to } 5 \\
\text { scale; } 5 \text { denotes most } \\
\text { rigid }\end{array}$ & $\begin{array}{l}\text { Average annual rain } \\
\text { level: inches per year }\end{array}$ & $\begin{array}{l}\text { Extent of irrigation: } 1 \\
\text { to } 5 \text { scale, } 5 \text { denotes } \\
\text { the most extensive }\end{array}$ \\
\hline \multirow[b]{2}{*}{ Kerala } & Western portion & $<302$ & \multirow[b]{2}{*}{5} & \multirow[b]{2}{*}{$100-120$} & \multirow[b]{2}{*}{1} \\
\hline & $\begin{array}{l}\text { Madras Presidency } \\
\text { and States }\end{array}$ & 302 & & & \\
\hline Coromandel & Eastern portion & $>302$ & 4 & $30-40$ & 2 \\
\hline Upper Ganges & $\begin{array}{l}\text { United Provinces and } \\
\text { States } \\
\end{array}$ & 427 & 3 & $30-40$ & 3 \\
\hline Middle Indus & $\begin{array}{c}\text { Punjab and NW } \\
\text { States }\end{array}$ & 177 & 2 & $<20$ & 5 \\
\hline Bengal Delta & Bengal and States & 551 & 1 & $90-100$ & ? \\
\hline \multicolumn{6}{|c|}{$\begin{array}{l}\text { Notes: The population to land ratios are derived from the } 1911 \text { Census of India, General Report (London: 1914), pp. 12-27. The source for the caste ranking is } \\
\text { M. Marriott, Caste Ranking and Community Structure in Five Regions of India and Pakistan (Poona, India: Deccan College Postgraduate and Research Institute, } \\
\text { 1965). The average annual rain level and extent of irrigation are derived from the } 1911 \text { Census of India, pp. 12-27. 82: the 1891 Census of India, General Report } \\
\text { (London: 1893), pp. 9-41, 74: and the } 1911 \text { Census of India, Travancore, Part III, vol. } 23 \text { (Trivandrum: 1912). }\end{array}$} \\
\hline
\end{tabular}

